\title{
A Sámi Community Wins Case against the Swedish State in the Supreme Court
}

\author{
Øyvind Ravna \\ UiT The Arctic University of Norway
}

On 23 January 2020, the Supreme Court of Sweden delivered an historic verdict in favour of the Girjas sameby in a lawsuit against the Swedish State over a long-standing dispute over the right to administer hunting and fishing rights in the Girjas land management area. Rooted in Sámi customary law, ILO Convention 169 and the UN Declaration of Indigenous Peoples, the verdict is a milestone in the development of Sámi law in Sweden. It may also have an impact on the other Nordic countries, in particular Norway.

The ruling by the Supreme Court of Sweden has put an end to a more than 10-year dispute between Girjas sameby (the Girjas Sámi reindeer herding community) and the Swedish State. ${ }^{1}$ The Girjas sameby claimed the exclusive right to manage hunting and fishing in their herding areas above the so-called odlingsgränsen (agricultural boundary) in Norrbotten län (county) in northwestern Sweden. According to Girjas, this right is either anchored in the Swedish Reindeer Husbandry Act (1971:437) or in immemorial use (urminnes hävd). The Swedish State, however, claimed that the state as landowner solely holds these rights.

Prior to this ruling, the rights of the Girjas sameby to hunt and fish in their areas of reindeer husbandry were considered to be enshrined in the Swedish Reindeer Husbandry Act, much as the rights of reindeer herders in Norway are enshrined in the Norwegian Reindeer Husbandry Act. However, similar to Norway, Swedish law does not allow the Sámi community, or its members, to decide whether others should be granted hunting and fishing permits in Sámi traditional lands. This authority lies with the county administrative board and is rooted in principles enshrined in a reindeer husbandry act from as early as 1886 , a law which is no longer applicable in Sweden.

In its lengthy and comprehensive 92-page verdict, the Supreme Court rules that Girjas sameby holds the exclusive right to manage hunting and fishing in its area, 
although the Reindeer Husbandry Act says otherwise. The Court anchors its judgment in Sámi customary law and immemorial use (urminnes hävd). The Court's verdict is also based on obligations under international law set forth, most importantly, in the ILO Convention No. 169 on indigenous peoples and tribal peoples in independent countries (ILO 169). The Court's ruling means that, in addition to their own hunting and fishing, Girjas sameby may issue permits to others to hunt and fish in the area, while the Swedish State cannot do the same.

Most surprisingly, the Supreme Court actively uses ILO 169 (article 8) to justify the use of Sámi customs, and thus the rights of the Sámi community. This is unexpected, because Sweden, unlike Norway, has not ratified ILO 169, and it is thus not legally binding on Sweden as a treaty. Nevertheless, the fact that the Court goes further in using ILO 169 than the courts in Norway do, is justified by the fact that the Court finds that the convention "expresses a general principle of international law" - in other words, the Supreme Court considers ILO 169 to be international customary law binding nation states without an act of incorporation. Based on this acknowledgement, the Court finds that the principle must be applied in resolving disputes related to "land rights affecting the Sámi", which means "that a Sámi custom which has been established must be taken into account" (para. 130).

Similarly, the Court has actively applied the UN Declaration on the Rights of Indigenous Peoples (UNDRIP). Unlike the Supreme Court of Norway, which in the Nesseby case (HR-2018-456-P) stated that the declaration was neither legally binding nor of direct significance to the case (para. 97), the Supreme Court of Sweden uses UNDRIP Article 26 on land rights to conclude that "an indigenous people [has] the right to the lands, territories and resources which it has traditionally owned, occupied or otherwise used or acquired" (para. 131), and subsequently that the right to manage hunting and fishing is rooted in immemorial use.

The Court ruling does not emphasize the State's activities and dispositions as evidence of the State's right to administer hunting and fishing permits. This stands in contrast to Norwegian case law where the Supreme Court in the Stjernøya (HR-2016-2030-A) and Nesseby cases emphasizes the State's disposition to reject the existence of the rights of others, or to justify that the State has erased such rights. The Supreme Court of Sweden does not find that such governmental acts, mainly exercised through a vague mix of authority and ownership, justify obliterating rights the Sámi evidently already had in the 18th century.

For the Sámi have had land use rights since at least the 18 th century. That is what the Supreme Court concludes after drawing on evidence back to the 16th century, and in their observation that Sámi rights to decide on hunting and fishing in the area were clearly established by the mid-18th century. The Court also concludes that before that time, the State had not asserted governing rights over these resources. This means, according to the Court, that hunting and fishing rights, including jurisdiction over these rights, has lain with the Sámi in the area since the mid-1700s. 
Although the State frequently challenged the Sámi right to manage resources, this did not, according to the Court, mean that Sámi rights to hunting and fishing ceased. These rights still prevailed when the Reindeer Husbandry Act of 1886 was adopted. The Court also states that Sámi jurisdiction over hunting and fishing in the 19th century was passed on to members of the Girjas sameby, which now holds exclusive rights to issue licenses for hunting and fishing in its management area. Girjas sameby is the body that manages members' collective rights.

The Girjas case is not only of great importance to Sámi communities in Sweden, but in Norway as well. Even though Swedish jurisprudence is generally of limited importance in Norway, it is different in the area of Sámi law. The Sámi people span four countries and share common cultures, languages and traditions, including customs and customary law, while the legal systems in Sweden and Norway are closely related. In addition, specific livelihood conditions involving land and water use are similar across the traditional Sámi lands. The fact that the Supreme Court has anchored its decision in ILO Convention 169, which has been ratified by Norway but not Sweden, is likely to reinforce the significance of the verdict in Norway.

Due to Sámi usage and custom, the Swedish Supreme Court verdict could therefore be of considerable importance to Norwegian case law. It will undoubtedly apply not only in the areas where the Norwegian State is the landowner, but also in Sápmi areas where associations whose rights are anchored in the State's previous dispositions, such as Finnmark Estate, are considered the landowner.

With the Girjas verdict, the Swedish Supreme Court will serve as a beacon in a legal landscape that in recent years has become more uncertain and difficult to navigate in Norway. The Swedish Supreme Court's use of ILO 169 shows that Swedish law takes the requirements of international law seriously, which will make it difficult for Norwegian courts to continue to state that ILO 169 does not have "material significance" for the legal survey in the Sámi areas in Norway and cannot be used to justify land use rights. The Girjas judgement signals a new direction not only in Swedish law, but also in our Nordic legal community. It will be exciting to see its full implications, including whether Sweden is now in the driver's seat regarding the promotion and development of indigenous law internationally.

\section{NOTE}

1. The decision (Högsta domstolen mål: T 853-18) is available in Swedish here: https://www. domstol.se/globalassets/filer/domstol/hogstadomstolen/avgoranden/2019/t-853-18.pdf (accessed 4 February 2020). 